\title{
REACTOGENICITY AND MEDICALLY ATTENDED ADVERSE EVENTS FOLLOWING HEXAVALENT VACCINATION: AN OBSERVATIONAL PROSPECTIVE STUDY
}

\author{
NOÉMI-BEÁTRIX BULIK ${ }^{1}$, CAMELIA BUCȘA ${ }^{2 *}$, DANIEL LEUCUȚA ${ }^{3}$, ANDREEA FARCAȘ $^{2}$, \\ ANAMARIA CRISTINA ${ }^{4}$, SANDRA MUREȘAN ${ }^{5}$, IOAN MUREȘAN ${ }^{6}$, OVIDIU ONIGA $^{1}$ \\ ${ }^{1}$ Pharmaceutical Chemistry Department, "Iuliu Hațieganu” University of Medicine and Pharmacy, 41 Victor Babeș Street, \\ 400012, Cluj-Napoca, Romania \\ ${ }^{2}$ Drug Information Research Centre, "Iuliu Hațieganu” University of Medicine and Pharmacy, 6 Louis Pasteur Street, \\ 400349, Cluj-Napoca, Romania \\ ${ }^{3}$ Department of Medical Informatics and Biostatistics, "Iuliu Hațieganu” University of Medicine and Pharmacy, 6 Louis \\ Pasteur Street, 400012, Cluj-Napoca, Romania \\ ${ }^{4}$ Department of Pharmacology, Physiology and Pathophysiology, "Iuliu Hațieganu” University of Medicine and Pharmacy, \\ 6 Louis Pasteur Street, 400349, Cluj-Napoca, Romania \\ 5 "Sandra Mureșan" medical practice, 32 Moților Street, 400001, Cluj-Napoca, Romania \\ 6 "Ioan Mureșan” medical practice, 5 Grigore Alexandrescu Street, 400515, Cluj-Napoca, Romania
}

*corresponding author: cfarah@umfcluj.com

Manuscript received: May 2019

\begin{abstract}
Any vaccine related safety issue leads to loss of parents' confidence in vaccines. This observational prospective study aimed to assess the reactogenicity and medically attended adverse events (MAEs) reported after the hexavalent vaccination (diphtheria-tetanus-pertussis toxoid, inactivated poliomyelitis virus, antigens against hepatitis B and Haemophilus influenzae type B polysaccharide). Children, vaccinated with the hexavalent vaccine in two general practitioner's offices between March 2016 and April 2017 according to the national immunization schedule from Romania, were included in the study. Reactogenicity and MAEs were assessed for 4 days post-vaccination and during 6 months post-vaccination, respectively. A total of 211 children were included in the study. The hexavalent vaccine was administered alone (Hexa alone) in 255 visits and together with other paediatric vaccines (Hexa co-ad) in 101 visits. Pain was the most frequently reported solicited local symptom regardless if the hexavalent vaccine was administered alone or co-administered with other paediatric vaccines (26.1\% vs. 31.3\%). Fever was more frequently reported in Hexa co-ad group as compared to Hexa alone (28.1\% vs. $13.7 \%)$. Infectious diseases were the majority of reported MAEs. 13 serious AEs and no death were recorded. Overall, this study confirmed the known safety profile of the hexavalent vaccine.
\end{abstract}

\section{Rezumat}

Siguranța vaccinurilor afectează decizia părinților de a vaccina copiii. Studiul de față a avut ca obiectiv evaluarea reactogenicității vaccinului hexavalent şi evenimentelor adverse evaluate medical (EAM) raportate după vaccinare. Au fost incluși în studiu copiii vaccinați conform schemei naționale de imunizare în două cabinete de medicină de familie între martie 2016 și aprilie 2017. Reactogenitatea a fost evaluată la 4 zile și EAM timp de 6 luni după vaccinare. 211 de copii au fost incluşi în studiu. 255 doze de vaccin hexavalent au fost administrate singure şi 101 doze au fost co-administrate cu alte vaccinuri. Durerea a fost cea mai frecventă reacție locală raportată, indifferent dacă vaccinul hexavalent a fost administrat singur sau co-administrat cu alte vaccinuri $(26.1 \%$ vs. $31.3 \%)$. Febra a fost mai frecvent raportată când vaccinul hexavalent a fost co-administrat $\mathrm{cu}$ altevaccinuri în comparaţie cu vaccinul administrat singur (28.1\% vs. 13.7\%). Infecțiile au fost majoritatea EAM raportate. 13 EA grave au fost raportate și niciun caz de deces. Acest studiu confirmă informațiile de siguranță ale vaccinului hexavalent.

Keywords: hexavalent vaccine, children, vaccine safety, adverse events

\section{Introduction}

The hexavalent combination vaccines containing diphtheria-tetanus-acellular pertussis (DTPa) toxoid, inactivated poliomyelitis virus (IPV), antigens against hepatitis B (HBV) and Haemophilus influenzae type B (Hib) polysaccharide are routinely used in twenty European countries [19] in different vaccination schemes
$(3+1$ or $2+1)$ [6]. In Romania this vaccine is administered at 2, 4 and 11 months of age according to the national immunization schedule [18].

The hexavalent vaccine has many advantages, including immunization schedule simplification, reduction in the number of injections administered at a single visit, lower incidence of the local reactions and reduced exposure to preservatives and stabilizers $[8,11,19,20]$. 
Nevertheless, the World Health Organization (WHO) estimated that 19.9 million infants did not receive the $3^{\text {rd }}$ dose of DTP vaccine up to 1 year of age in 2017 [28]. In Romania only 82\% of the children received all the 3 doses of DTP vaccine in 2017 [27]. Although many barriers limit the vaccination coverage, studies have shown that vaccine hesitancy is one of the main reasons for under-vaccination $[4,7,10]$. Vaccine hesitancy can lead to immunization refusal, and by those risking disease outbreaks (i.e., pertussis and measles outbreaks). The concerns over the vaccine safety are one of the most important factors that lead to vaccine hesitancy among healthcare providers and parents $[4,15,16,26]$. As the healthcare providers are the most trusted advisors of vaccine related information for patients, it is important to increase their knowledge in vaccines safety by providing realworld observational data [5, 21]. In a qualitative study conducted in 4 countries from EU (Croatia, France, Greece and Romania), the majority of the health care providers considered important to respond to patient hesitancy using scientific evidence [5]. Data from a real-world study could support the healthcare professionals' efforts to enhance the public confidence in vaccines.

The purpose of this study was to assess the reactogenicity and medically attended adverse events (MAEs) after the immunization with hexavalent vaccine.

\section{Materials and Methods}

\section{Study design}

The current observational, prospective study assessed the reactogenicity of the hexavalent vaccine and MAEs following the hexavalent vaccination in 2 general practitioner (GP) offices from Cluj-Napoca, Romania. This study was approved by the Ethics Committee of "Iuliu Hațieganu" University of Medicine and Pharmacy, Cluj-Napoca, Romania, and was conducted according to the principles of Good Clinical Practice and the Declaration of Helsinki.

\section{Study population}

Children vaccinated during March 2016 - April 2017 were included in the study. The children's parents were invited to participate and sign the informed consent form. We included all children vaccinated with the hexavalent vaccine, irrespective of the dose number.

The hexavalent vaccine was administered intramuscularly alone (Hexa alone) or together with other paediatric vaccines (Hexa co-ad). For reason of absence from the Romanian market of the hexavalent vaccine, some children received Infanrix IPV/HIB ${ }^{\circledR}$ together with Engerix $\mathrm{B}^{\circledR}$ paediatric instead of hexavalent vaccine. The AEs reported after Infanrix IPV/HIB ${ }^{\circledR}+$ Engerix $\mathrm{B}^{\circledR}$ paediatric are presented cumulated with the results of hexavalent vaccine and considered as 1 dose of hexavalent vaccine, as studies have shown no significant differences in the safety of these vaccines [1, 14]. Pneumococcal conjugate vaccine (PCV), rotavirus, varicella and hepatitis $\mathrm{A}$ vaccines were recommended and administered in some cases by the GPs in addition to the hexavalent vaccine (were available for private purchase). The results of the hexavalent vaccine administered together with the measles-mumps-rubella vaccine are not presented in this paper.

\section{Outcome measures}

We collected demographic characteristics of the children (gender, gestational age at birth, birth weight and allergies), history of feeding (breastfeeding or formula, diversification age, food intolerances), medical history of the children, and AEs occurred after prior vaccinations during the $1^{\text {st }}$ vaccination visit.

At each vaccination visit, we collected data regarding the changes in children's diet within one week prior to vaccination, all diseases that occurred between the vaccination visits, any drugs used one month prior to vaccination, and details regarding the vaccination (age at vaccination, vaccines' name).

Solicited local symptoms (pain, redness, swelling) and general symptoms (fever, irritability, loss of appetite, diarrhoea, vomiting) were collected via an online questionnaire for days 0 - 3 after each vaccination. Symptom intensity was graded on a 0 - 3 scale. Grade 3 symptoms were defined as crying when the limb was moved for pain, $>30 \mathrm{~mm}$ in diameter for redness and swelling, rectal temperature $\geq 40.0^{\circ} \mathrm{C}$ for fever, inconsolable crying for irritability, not eating at all for loss of appetite, $\geq 5$ looser than normal stools per day for diarrhoea, and parenteral rehydration for vomiting. Also, we collected data on the occurrence of sleep disturbances (sleeping more than usual/falling asleep hard/sleeping less than usual), cough and rhinitis.

The MAEs and serious AEs (SAEs) were collected for 6 months post-vaccination from the medical charts and phone interviews. SAEs were defined according to WHO [29].

Statistical analysis

Descriptive statistics (counts and percentages) were used to describe children characteristics. Continuous variables were presented as median and range. The incidence of solicited local and general symptoms (overall and grade 3) was presented in terms of the percentages of doses with $95 \%$ binomial confidence intervals (CI). All analyses were performed in $\mathrm{R}$ environment for statistical computing and graphics ( $\mathrm{R}$ Foundation for Statistical Computing, Vienna, Austria), version 3.4.4.

\section{Results and Discussion}

A total of 211 children were included in the study (total vaccinated cohort) and 205 children were included in the follow-up cohort. A total of 11 children were 
lost to follow-up: 9 moved to another area and 2 did not respond to phone calls. 5 from 11 children were included in the follow-up cohort up to the dropping off point. Demographic characteristics are presented in Table I.

Demographic characteristics, medical and feeding history of the vaccinated children (total vaccinated cohort)

\begin{tabular}{lc}
\hline \multicolumn{2}{c}{ Baseline characteristic (N=211) } \\
\hline Age at enrolment (months, median, [range]) \\
Gender (female, number, \%) & $4[2-17]$ \\
Premature (<37 weeks, number, \%) & $115(54.5)$ \\
Birth weight (g, median, [range]) & $13(6.2)$ \\
Breastfeeding alone/associated with formula (number, \%) & $3300[1360-4850]$ \\
Food intolerance (number, \%) & $149(70.6)$ \\
Allergies (number, \%) & $6(2.8)$ \\
Medical history (number, \%) & $7(3.3)$ \\
$\quad$ Bronchitis & $12(5.7)$ \\
Upper respiratory tract infection & $56(26.5)$ \\
Otitis media & $2(0.9)$ \\
Gastrointestinal disorders & $15(6.6)$ \\
Atopic dermatitis & $11(5.2)$ \\
Other & \\
Chronic diseases (number, \%) & $24(11.4)$ \\
Adverse events after prior vaccination (number, \%) & $10(4.7)$ \\
\hline
\end{tabular}

${ }^{1}$ Other diseases in the medical history were rhinitis, pneumonia, anaemia, conjunctivitis, dehydration, eczema, viral rash and congenital hypothyroidism.

The vaccines used for immunization were Hexacima ${ }^{\circledR}$ (offered free of charge by the Romanian state [in 291 vaccination visits]), Infanrix hexa ${ }^{\circledR}$ (bought by the parents if they have chosen to [in 11 vaccination

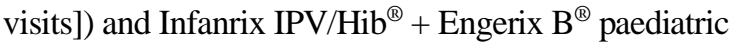
(in 54 vaccination visits). The hexavalent vaccine was administered alone in 255 vaccination visits and co- administered with other paediatric vaccines in 101 vaccination visits.

The number of children vaccinated at each dose is presented in Table II. PCV was co-administered with the hexavalent vaccine in $85.5 \%$ of the coadministered doses.

Table II

The number of children and their age range at each vaccination dose (total vaccinated cohort)

\begin{tabular}{lcc}
\hline Vaccine dose & $\begin{array}{c}\text { Hexa alone }(\mathbf{N}=\mathbf{1 3 5} \text { ) } \\
\text { Age at vaccination } \\
\text { (number of children [months, range]) }\end{array}$ & $\begin{array}{c}\text { Hexa co-ad }(\mathbf{N}=\mathbf{7 6} \text { ) } \\
\text { Age at vaccination }\end{array}$ \\
\hline Dose 1 & $79(2-5)$ & $40(2-5)$ \\
Dose 2 & $97(4-9)$ & $39(4-7)$ \\
Dose 3 & $65(11-17)$ & $17(11-15)$ \\
\hline
\end{tabular}

$\mathrm{N}$, number of children in a given group; Hexa, hexavalent vaccine; Hexa co-ad, children with at least one dose of hexavalent vaccine administered together with other paediatric vaccines

\section{Solicited local and general symptoms}

The 211 children were vaccinated in 356 visits. We received 337 questionnaires of reactogenicity (a response rate of $94.9 \%$ ).

The incidence of solicited local symptoms per questionnaire is presented in Table III. The highest reported incidence was for pain, in the Hexa co-ad group, after the $3^{\text {rd }}$ dose $(58.8 \%$; $95 \%$ CI 32.9 - 81.6). The incidence of redness and swelling seemed to increase with the dose number. It has been shown that the incidence and severity of local symptoms, especially swelling for DTPa vaccines, increases with age, additional doses of vaccine, and pre-vaccination antibody concentration $[11,32]$. Large swelling at the injection site is also expected, although it occurs more frequently after the $4^{\text {th }}$ and $5^{\text {th }}$ doses. Large swelling was not reported in our study.
The incidence of solicited general symptoms per questionnnare is presented in Table IV. The most reported solicited general symptom was irritability in our study, while other research found fever to be the most frequent one $[4,20]$. After irritability, fever was the $2^{\text {nd }}$ most frequently reported solicited general symptom in our study. Fever incidence seemed to increase after successive dose in Hexa co-ad group, this being consistent with the findings of Jackson et al. regarding the increase of fever after successive DTPa vaccine [13]. This pattern was not applicable though for the Hexa alone group.

Overall, the incidence of fever was higher in Hexa co-ad group as compared with Hexa alone $(28.1 \%$ [95\% CI 19.4 - 38.2] vs. 13.7\% [95\% CI 9.6 - 18.7]). An increased fever when the hexavalent vaccine is coadministered with other paediatric vaccines, especially 
FARMACIA, 2019, Vol. 67, 6

with the PCV, is expected and listed in the summary of product information (SmPC) $[12,31]$. Fever $\geq 40^{\circ} \mathrm{C}$ was reported in our study only for 1 child after the hexavalent vaccine (dose 3 ) co-administered with PCV.

Some studies found that fever is a main concern for parents and healthcare providers. For this reason, fever is treated even if not necessary and even more, preventive antipyretics are administered [17, 24]. This behaviour was found to be mainly due to parents' fear of febrile seizures. Febrile seizures may occur after 6 months of age, especially after dose 3 of hexavalent vaccine, but their incidence is very low [9]. No febrile seizure was reported in our study.

Table III

Incidence of solicited local symptoms collected for days 0 - 3 after vaccination per questionnaire (total vaccinated cohort)

\begin{tabular}{ccccccccc}
\hline $\begin{array}{c}\text { Symptom } \\
\text { \% }\end{array}$ & \multicolumn{9}{c}{ Hexa alone } & \multicolumn{4}{c}{ Hexa co-ad } \\
\cline { 2 - 8 }$(\mathbf{9 5 \%}$ CI $)$ & $\begin{array}{c}\text { Dose } 1 \\
(\mathrm{n}=79)\end{array}$ & $\begin{array}{c}\text { Dose } 2 \\
(\mathrm{n}=97)\end{array}$ & $\begin{array}{c}\text { Dose 3 } \\
(\mathrm{n}=65)\end{array}$ & $\begin{array}{c}\text { Overall } \\
(\mathrm{n}=241)\end{array}$ & $\begin{array}{c}\text { Dose } 1 \\
(\mathrm{n}=40)\end{array}$ & $\begin{array}{c}\text { Dose 2 } \\
(\mathrm{n}=39)\end{array}$ & $\begin{array}{c}\text { Dose 3 } \\
(\mathrm{n}=17)\end{array}$ & $\begin{array}{c}\text { Overall } \\
(\mathrm{n}=96)\end{array}$ \\
\hline Pain & 30.4 & 21.7 & 27.7 & 26.1 & 30.0 & 20.5 & 58.8 & 31.3 \\
$($ Any) & $(20.5-41.8)$ & $(13.9-31.2)$ & $(17.3-40.2)$ & $(27.1-32.2)$ & $(16.6-46.5)$ & $(9.3-36.5)$ & $(32.9-81.6)$ & $(22.2-41.5)$ \\
Grade 3 & 3.8 & 1.1 & 6.2 & 3.3 & 0.0 & 5.1 & 5.9 & 4.2 \\
& $(0.8-10.7)$ & $(0.0-5.6)$ & $(1.7-15.0)$ & $(1.4-6.4)$ & $(0.0-8.8)$ & $(0.6-17.3)$ & $(0.2-28.7)$ & $(1.2-10.3)$ \\
\hline Redness & 13.9 & 25.8 & 26.2 & 22.0 & 5.0 & 18.0 & 41.2 & 16.7 \\
(Any) & $(7.2-23.6)$ & $(17.4-35.7)$ & $(16.0-38.5)$ & $(16.9-27.8)$ & $(0.6-16.9)$ & $(7.5-33.5)$ & $(18.4-67.1)$ & $(9.8-25.7)$ \\
Grade 3 & 3.8 & 0.0 & 4.6 & 2.5 & 0.0 & 2.6 & 11.8 & 3.1 \\
& $(0.8-10.7)$ & $(0.0-3.7)$ & $(1.0-12.9)$ & $(0.9-5.3)$ & $(0.0-8.8)$ & $(0.1-13.5)$ & $(1.5-36.4)$ & $(0.7-8.9)$ \\
\hline Swelling & 7.6 & 13.4 & 16.9 & 12.5 & 5.0 & 7.7 & 35.3 & 11.5 \\
(Any) & $(2.8-15.8)$ & $(7.3-21.8)$ & $(8.8-28.3)$ & $(18.6-17.3)$ & $(0.6-16.9)$ & $(1.6-20.9)$ & $(14.2-61.7)$ & $(5.9-19.6)$ \\
Grade 3 & 2.5 & 0.0 & 0.0 & 0.8 & 0.0 & 0.0 & 5.9 & 1.0 \\
& $(0.3-8.9)$ & $(0.0-3.7)$ & $(0.0-5.5)$ & $(0.1-3.0)$ & $(0.0-8.8)$ & $(0.0-9.0)$ & $(0.2-28.7)$ & $(0.0-5.7)$ \\
\hline
\end{tabular}

$\mathrm{n}$, number of vaccine doses; For the children vaccinated with Infanrix IPV/Hib ${ }^{\circledR}+$ Engerix $\mathrm{B}^{\circledR}$ paediatric any AE reported in the questionnaire was considered; Hexa, hexavalent vaccine; Hexa co-ad, hexavalent vaccine and other paediatric vaccines administered at the same visit; Grade 3, crying when injection limb was moved or the movement of the injected limb is reduced for pain; diameter $>30$ mm for redness and swelling.

Table IV

Incidences of solicited general symptoms collected for days 0-3 after vaccination per questionnaire (total

\begin{tabular}{|c|c|c|c|c|c|c|c|c|}
\hline Symptom & & Hexa & alone & & & Hexa & co-ad & \\
\hline$\%$ & $\begin{array}{c}\text { Dose } 1 \\
(\mathrm{n}=79)\end{array}$ & $\begin{array}{c}\text { Dose } 2 \\
(\mathrm{n}=97)\end{array}$ & Dose 3 & & & Dose 2 & Dose 3 & \\
\hline $\begin{array}{c}\text { Fever } \\
\left(>38^{\circ} \mathrm{C}\right)\end{array}$ & $\begin{array}{c}16.5 \\
(9.1-26.5)\end{array}$ & $\begin{array}{c}11.3 \\
(5.8-19.4)\end{array}$ & $\begin{array}{c}13.9 \\
(6.5-24.7)\end{array}$ & $\begin{array}{c}13.7 \\
(9.6-18.7)\end{array}$ & $\begin{array}{c}22.5 \\
(10.8-38.5)\end{array}$ & $\begin{array}{c}30.8 \\
(17.0-47.6)\end{array}$ & $\begin{array}{c}35.3 \\
(14.2-61.7)\end{array}$ & $(19.4-38.2)$ \\
\hline Grade 3 & $\begin{array}{c}0.0 \\
(0.0-4.6)\end{array}$ & $\begin{array}{c}0.0 \\
(0.0-3.7)\end{array}$ & $\begin{array}{c}0.0 \\
(0.0-5.5)\end{array}$ & $\begin{array}{c}0.0 \\
(0.0-1.5)\end{array}$ & $\begin{array}{c}0.0 \\
(0.0-8.8)\end{array}$ & $\begin{array}{c}0.0 \\
(0.0-9.0)\end{array}$ & $\begin{array}{c}5.9 \\
(0.2-28.7)\end{array}$ & (0.0 \\
\hline $\begin{array}{l}\text { ritabilit } \\
\mathbf{y}\end{array}$ & $\begin{array}{c}48.1 \\
(36.7-59.6)\end{array}$ & $\begin{array}{c}45.4 \\
(35.2-55.8)\end{array}$ & $\begin{array}{c}40.0 \\
(28.0-52.9)\end{array}$ & $\begin{array}{c}44.8 \\
(38.4-51.3)\end{array}$ & $\begin{array}{c}57.5 \\
(40.9-73.0)\end{array}$ & $\begin{array}{c}51.3 \\
(34.8-67.6)\end{array}$ & $\begin{array}{c}70.6 \\
(44.0-89.7)\end{array}$ & $(46.8$ \\
\hline $\begin{array}{c}\text { (Any) } \\
\text { Grade } 3\end{array}$ & $\begin{array}{c}7.6 \\
(2.8-15.8)\end{array}$ & $\begin{array}{c}2.1 \\
(0.3-7.3)\end{array}$ & $\begin{array}{c}4.6 \\
(1.0-12.1)\end{array}$ & $\begin{array}{c}4.6 \\
(2.3-8.0)\end{array}$ & $\begin{array}{c}7.5 \\
(1.6-20.4)\end{array}$ & $\begin{array}{c}2.6 \\
(0.1-13.5)\end{array}$ & $\begin{array}{c}5.9 \\
(0.2-28.7)\end{array}$ & 1.7) \\
\hline $\begin{array}{l}\text { Loss of } \\
\text { appetite }\end{array}$ & $\begin{array}{c}17.7 \\
(10.0-27.9)\end{array}$ & $\begin{array}{c}19.6 \\
(12.2-28.9)\end{array}$ & $\begin{array}{c}32.3 \\
(21.3-45.1)\end{array}$ & $\begin{array}{c}22.4 \\
(17.3-28.2)\end{array}$ & $\begin{array}{c}30.0 \\
(16.6-46.5)\end{array}$ & $\begin{array}{c}23.1 \\
(11.1-39.3)\end{array}$ & $\begin{array}{c}47.1 \\
(23.0-72.2)\end{array}$ & $\begin{array}{c}30.2 \\
(21.3-40.4)\end{array}$ \\
\hline $\begin{array}{c}\text { (Any) } \\
\text { Grade } 3\end{array}$ & $\begin{array}{c}1.3 \\
(0.0-6.9)\end{array}$ & $\begin{array}{c}0.0 \\
(0.0-3.7)\end{array}$ & $(0.0-8.3)$ & $(0.1$ & $\begin{array}{r}0 . \\
(0.0-\end{array}$ & $(0.0-9.0)$ & $\begin{array}{c}0.0 \\
(0.0-19.5)\end{array}$ & $(0.0$ \\
\hline $\begin{array}{l}\text { Diarrhoea } \\
\text { (Any) }\end{array}$ & $\begin{array}{c}8.9 \\
(3.6-17.4)\end{array}$ & $\begin{array}{c}12.4 \\
(6.6-20.6)\end{array}$ & $\begin{array}{c}12.3 \\
(5.5-22.8)\end{array}$ & $\begin{array}{c}11.2 \\
(7.5-15.9)\end{array}$ & $\begin{array}{c}10.0 \\
(2.8-23.7)\end{array}$ & $\begin{array}{c}10.3 \\
(2.9-24.2)\end{array}$ & $\begin{array}{c}29.4 \\
(10.3-56.0)\end{array}$ & $\begin{array}{c}13.5 \\
(7.4-22.0)\end{array}$ \\
\hline Grade 3 & $\begin{array}{c}0.0 \\
(0.0-4.6)\end{array}$ & $\begin{array}{c}0.0 \\
(0.0-3.7)\end{array}$ & $\begin{array}{c}0.0 \\
(0.0-5.5)\end{array}$ & $\begin{array}{c}0.0 \\
(0.0-1.5)\end{array}$ & $\begin{array}{c}0.0 \\
(0.0-8.8\end{array}$ & $\begin{array}{c}0.0 \\
(0.0-9.0)\end{array}$ & $\begin{array}{c}0.0 \\
(0.0-19.5)\end{array}$ & $\begin{array}{c}0.0 \\
(0.0-3 .\end{array}$ \\
\hline $\begin{array}{l}\text { Vomiting } \\
\text { (Any) }\end{array}$ & $\begin{array}{c}12.7 \\
(6.2-22.1)\end{array}$ & $\begin{array}{c}7.2 \\
(3.0-14.3)\end{array}$ & $\begin{array}{c}9.2 \\
(3.5-19.0)\end{array}$ & $\begin{array}{c}9.5 \\
(6.2-14.0)\end{array}$ & $\begin{array}{c}12.5 \\
(4.2-26.8)\end{array}$ & $\begin{array}{c}10.3 \\
(2.9-24.2)\end{array}$ & $\begin{array}{c}5.9 \\
(0.2-28.7)\end{array}$ & $\begin{array}{c}10.4 \\
(5.1-18.3)\end{array}$ \\
\hline Grade 3 & $\begin{array}{c}0.0 \\
(0.0-4.6)\end{array}$ & $\begin{array}{c}0.0 \\
(0.0-3.7)\end{array}$ & $\begin{array}{c}1.5 \\
(0.0-8.3)\end{array}$ & $\begin{array}{c}0.4 \\
(0.0-2.3)\end{array}$ & $\begin{array}{c}0.0 \\
(0.0-8.8)\end{array}$ & $\begin{array}{c}0.0 \\
(0.0-9.0)\end{array}$ & $\begin{array}{c}0.0 \\
(0.0-19.5)\end{array}$ & $\begin{array}{c}0.0 \\
(0.0-3.8)\end{array}$ \\
\hline
\end{tabular}

$\mathrm{n}$, number of vaccine doses; Hexa, hexavalent vaccine; Hexa co-ad, hexavalent vaccine and other paediatric vaccines administered at the same visit; Grade $3, \geq 40^{\circ} \mathrm{C}$ for fever; inconsolable, persisting crying for irritability; not eating at all for loss of appetite; $\geq 5$ stools for diarrhoea; parenteral rehydration for vomiting.

Antipyretic drugs were used after 120/337 (35.6\%) doses of hexavalent vaccine $(81 / 241$ doses [33.6\%] in Hexa alone and 39/96 doses [40.6\%] in Hexa coad). After 54 doses (21.2\%) in Hexa alone group and 
17 doses $(16.8 \%)$ in Hexa co-ad antipyretics were used prophylactically. The prophylactic administration of antipyretic drugs reduces the incidence of the local symptoms and fever, mainly in the infant series, while in toddlers this is controversial [22, 23]. Nevertheless, the prophylactic use of paracetamol decreases the response to diphtheria, tetanus and pertactin antigens [22] and prophylactic ibuprofen use could reduce the response to pertussis and tetanus antigens [30]. Drowsiness was reported after 75 doses of hexavalent vaccine (43 [17.8\%; 95\% CI 13.2 - 23.3] children in Hexa alone group and 32 [33.3\%; 95\% CI 24.0 - 43.7] in Hexa co-ad). Sleep disturbancies (sleep less the usual) were noted after 30 administered doses (21
[8.7\%; 95\% CI 5.5 - 13.0] children from Hexa alone group vs. 9 [9.4\%; 95\% CI 4.4 - 17.1] in Hexa co-ad). Dry cough was reported after $12(5.0 \%$; 95\% CI 2.6 $8.5)$ and 13 doses $(9.4 \%$; $95 \%$ CI $4.4-17.1)$ in the Hexa alone $v s$. Hexa co-ad, respectively. Rhinitis was reported after 11 doses $(4.6 \%$; 95\% CI $2.3-8.0)$ in Hexa alone and after 3 doses in Hexa co-ad (3.1\%; 95\% CI 0.7 - 8.9).

Medically attended adverse events (MAEs)

During the 6 months follow-up period, 244 AEs in 93 children and 105 AEs in 50 children urged medical visits in the Hexa alone vs. Hexa co-ad group, respectively (Table V).

Table V

Medically attended AEs collected during the 6 months follow-up period (follow-up cohort)

Hexa alone $(\mathbf{N}=\mathbf{1 3 0})$

Hexa co-ad $(\mathbf{N}=75)$

$\begin{array}{lcccccc}\text { Infections (any) } & -30 \text { days } & 31-90 \text { days } & 91-180 \text { days } & 0-30 \text { days } & 31-90 \text { days } & 91-180 \text { days } \\ \text { URTI } & \mathbf{3 0} & \mathbf{7 2} & \mathbf{1 1 2} & \mathbf{2 0} & \mathbf{3 8} & \mathbf{3 8} \\ \text { LRTI } & 18 & 55 & 81 & 11 & 30 & 30 \\ \text { Gastro-enterocolitis } & 4 & 5 & 11 & 5 & 4 & 3 \\ \text { Otitis media } & 2 & 6 & 9 & 2 & 2 & 2 \\ \text { Other } & 0 & 1 & 3 & 0 & 0 & 1 \\ \text { Skin conditions } & 6 & 5 & 9 & 2 & 2 & \mathbf{0} \\ \text { Urticaria } & \mathbf{5} & \mathbf{2} & \mathbf{1} & \mathbf{1} & \mathbf{0} & 0 \\ \text { Dermatitis } & 3 & 1 & 0 & 0 & 0 & 0 \\ \text { Eczema } & 2 & 1 & 1 & 0 & 0 & 0 \\ \text { GI conditions } & 0 & 0 & 0 & 1 & 0 & 0 \\ \text { GERD } & \mathbf{2} & \mathbf{4} & \mathbf{8} & \mathbf{3} & \mathbf{4} & 0 \\ \text { Diarrhoea } & 1 & 1 & 0 & 0 & 0 & 0 \\ \text { Irritable bowel } & 1 & 3 & 8 & 2 & 3 & 0 \\ \text { Hepatocytolisis } & 0 & 0 & 0 & 1 & 0 & 0 \\ \text { Other } & 0 & 0 & 0 & 0 & \mathbf{1} & 0 \\ \text { Anaemia } & \mathbf{1} & \mathbf{2} & \mathbf{5} & \mathbf{0} & 0 & 0 \\ \text { Fever } & 1 & 0 & 1 & 0 & 0 & 0 \\ \text { Asthma } & 0 & 2 & 1 & 0 & 0 & 0 \\ \text { Paroxysm } & 0 & 0 & 1 & 0 & 0 & 0 \\ \text { Spasmophilia } & 0 & 0 & 1 & 0 & 0 & 0 \\ \text { Seizure } & 0 & 0 & 0 & 0 & 43 & 0 \\ \text { Total } & 38 & 80 & 126 & 24 & 0\end{array}$

$\mathrm{N}$, number of children in each group; Hexa, hexavalent vaccine; Hexa co-ad, hexavalent vaccine and other paediatric vaccines administered at the same visit; URTI, upper respiratory tract infections; LRTI, lower respiratory tract infections; GI, gastrointestinal; GERD, gastroesophageal reflux disease; Fever, body temperature $>38^{\circ} \mathrm{C}$ not associated with other signs of infection.

The incidence of MAEs in the $1^{\text {st }}$ month after vaccination in the Hexa alone group (0.29 MAEs/children) was comparable with the incidence in the months $2-3$ (0.30 MAEs/children/month) and months 4 - 6 (0.32 MAEs/children/month). In the Hexa co-ad group, the incidence of MAEs in the $1^{\text {st }}$ month (0.32 MAEs/ children) was comparable with the incidence in the months 2 - 3 (0.29 MAEs/children/months) but higher as compared to the months 4 - 6 (0.17 MAEs/children/ months).

The incidence of MAEs in the $1^{\text {st }}$ month after vaccination was comparable between Hexa alone and Hexa co-ad groups. Similar results were presented in a review of the hexavalent vaccine safety reported in Europe, where the frequency of the unsolicited AEs reported during the $1^{\text {st }}$ month after vaccination was comparable between the hexavalent vaccine administered alone $(33.7 \%-51.1 \%)$ and co-administered with other paediatric vaccines $(17.7 \%-48.5 \%)$ [3].

Infectious diseases were the most frequently collected MAEs in both groups (87.7\% in Hexa alone and 91.4\% in Hexa co-ad). The incidence of lower respiratory tract infections (LRTIs) in the $1^{\text {st }}$ month was higher in the Hexa co-ad group as compared with Hexa alone (0.07 AEs/children/month vs. 0.03 AEs/children/ month). The incidence was comparable between the 2 groups for months 2 - 3 (0.03 AEs/children/months $v s$. $0.02 \mathrm{AEs} / \mathrm{children/months)}$ and months 4 - 6 (0.01 AEs/children/months vs. 0.02 AEs/children/months). Among LRTIs, 3 cases of pneumonia (in a time frame of 91 - 180 days after vaccination) were reported in the Hexa alone group as compared to none in the 
Hexa co-ad (as expected per the fact that $85 \%$ of the hexavalent vaccine doses were co-administered with PCV). This finding is probably due to the effectiveness of the PCV, found by Sigurdsson et al. to be $23 \%$ against pneumonia and otitis media [25]. The same study also observed an increased incidence $(53 \%)$ of bronchiolitis in children vaccinated with PCV. We found a comparable incidence of bronchiolitis in the 75 children $(10.7 \%)$ that received hexavalent vaccine together with PCV and in 130 children (9.2\%) in Hexa alone.

Serious adverse events (SAEs)

Of all MAEs, 13 SAEs were recorded in 13 children, and all led to hospitalization (11 SAEs in the Hexa alone group and 2 SAEs when the hexavalent vaccine was co-administered with PCV). These were 4 cases of gastroenterocolitis with onset 103 - 160 days after vaccination, 4 cases of bronchiolitis with onset 10 121 days after vaccination, 1 case of pneumonia at 97 days after vaccination, 2 cases of tonsillitis with onset 42 - 66 days after vaccination, 1 asthma and 1 hepatocytolisis at 70 days after vaccination. No death was reported. Same results were reported in a review of Infanrix hexa ${ }^{\circledR}$, where the infection diseases were the most frequently collected SAEs (gastrointestinal disorders, respiratory and urinary tract infections). These infections are common childhood diseases [32]. Limitations of our study are related to the relatively small number of children followed-up and the parents' potential recall bias for AEs that urged emergency unit or specialist visit. To overcome this limitation we collected data on these events from the medical charts in addition to the phone interview. Nevertheless, this study completes the post-authorization safety information of the hexavalent vaccine.

\section{Conclusions}

The overall incidence of solicited general symptoms after hexavalent vaccination in our study seemed to be higher when the hexavalent vaccine was coadministered with other paediatric vaccines, except vomiting and diarrhoea which seemed to be similar between the groups. The overall incidence of MAEs in the first month after vaccination was comparable when the hexavalent vaccine was administered alone as compared to the co-administration. However, the incidence of LRTIs in the first month was higher when the hexavalent vaccine was co-administered as compared to alone administration. The study completes the known safety profile of the hexavalent vaccine administered either alone or together with other paediatric vaccines.

\section{Conflicts of Interest}

The authors declare no conflict of interest.

\section{References}

1. Arístegui J, Dal-Ré R, Díez-Delgado J, Marés J, Casanovas JM, García-Corbeira P, De Frutos E, Van Esso D, Verdaguer J, De la Flor J, Moraga F, Boceta R, García-Martínez JA, Comparison of the reactogenicity and immunogenicity of a combined diphtheria, tetanus, acellular pertussis, hepatitis B, inactivated polio (DTPa-HBV-IPV) vaccine, mixed with the Haemophilus influenzae type $\mathrm{b}$ (Hib) conjugate vaccine and administered as a single injection, with the DTPa-IPV/Hib and hepatitis B vaccines administered at 2, 4 and 6 months of age. Vaccine, 2003; 21(25-26): 3593-3600.

2. Baldo V, Bonanni P, Castro M, Gabutti G, Franco E, Marchetti F, Prato R, Vitale F, Combined hexavalent diphtheria-tetanus-acellular pertussis-hepatitis Binactivated poliovirus-Haemophilus influenzae type $\mathrm{b}$ vaccine; Infanrix ${ }^{\mathrm{TM}}$ hexa. Twelve years of experience in Italy. Hum Vaccin Immunother., 2014; 10(1): 129137.

3. Bulik NB, Bucsa C, Farcas A, Oniga O, Hexavalent vaccine in Europe: safety data from the randomized clinical trials. Farmacia, 2018; 66(5): 747-757.

4. Dubé E, Laberge C, Guay M, Bramadat P, Roy R, Bettinger JA, Vaccine hesitancy. An overview. Hum Vaccin Immunother., 2013; 9(8): 1763-1773.

5. ECDC. Vaccine hesitancy mong healthcare workers and their patients in Europe. https://ecdc.europa.eu/ sites/portal/files/media/en/publications/Publications /vaccine-hesitancy-among-healthcare-workers.pdf.

6. ECDC. Vaccine scheduler. https://vaccine-schedule. ecdc.europa.eu.

7. Esposito S, Pincipi N, Cornaglia G, Barriers to the vaccination of children and adolescents and possible solutions. Clin Microbiol Infect., 2014; 20(Suppl. 5): 25-31.

8. Esposito S, Tagliabue C, Bosis S, Ierardi V, Gambino M, Principi N, Hexavalent vaccines for immunization in paediatric age. Clin Microbil Infect., 2014; 20 (Suppl. 5): 76-85.

9. Farrington P, Pugh S, Colville A, Flower A, Nash J, Morgan-Capner P, Rush M, Miller E, A new method for active surveillance of adverse events from diphtheria/tetanus/pertussis and measles/mumps/ rubella vaccines. Lancet, 1995; 345(8949): 567-569.

10. Favin M, Steinglass R, Fields R, Banerjee K, Sawhney $\mathrm{M}$, Why children are not vaccinated: a review of the grey literature. Int Health, 2012; 4(4): 229-238.

11. Halsey NA. Combination vaccines: defining and addressing current safety concerns. Clin Infect Dis., 2001; 33(Suppl. 4): S312-S318.

12. Infanrix hexa - Summary of product charachteristics. (available at www.ema.europa.eu)

13. Jackson L, Carste B, Malais D, Froeschle J, Retrospective population-based assessment of medically attended injection site reactions, seizures, allergic responses and febrile episodes after acellular pertussis vaccine combined with diphtheria and tetanus toxoids. Pediatr Infect Dis J., 2002; 21(8): 781-786.

14. Klein NP, Abu-Elyazeed R, Cheuvart B, Janssens W, Mesaros N, Immunogenicity and safety following primary and booster vaccination with a hexavalent diphtheria, tetanus, acellular pertussis, hepatitis B, 
inactivated poliovirus and Haemophilus influenzae type $b$ vaccine. A randomized trial in the United States. Hum Vaccin Immunother., 2019; 15(4): 809-821.

15. Lane S, MacDonald NE, Marti M, Dumolard L, Vaccine hesitancy around the globe: Analysis of three years of WHO/UNICEF Joint Reporting Form data-2015-2017. Vaccine, 2018; 36(26): 3861-3867.

16. Larson H, Smith D, Paterson P, Cumming M, Eckersberger E, Freifeld C, Ghinai I, Jarrett C, Paushter L, Brownstein JS, Madoff LC, Measuring vaccine confidence: analysis of data obtained by a media surveillance system used to analyse public concerns about vaccines. Lancet Infect Dis., 2013; 13(7): 606-613.

17. Martins M, Abecasis F, Healthcare professionals approach paediatric fever in significantly different ways and fever phobia is not just limited to parents. Acta Paediatr., 2016; 105(7): 829-833.

18. Ministry of Public Health. Information about mandatory vaccinations from National vaccination schedule (available at www.ms.ro, in Romanian).

19. Obando-Pacheco P, Rivero-Calle I, Gómez-Rial J, Rodríguez-Tenreiro Sánchez C, Martinón-Torres F, New perspectives for hexavalent vaccines. Vaccine, 2018; 36(36): 5485-5494.

20. Orsi A, Azzari C, Bozzola E, Chiamenti G, Chirico G, Esposito S, Francia F, Lopalco P, Prato R, Russo R, Villani A, Hexavalent vaccines: characteristics of available products and practical considerations from a panel of Italian experts. J Prev Med Hyg., 2018; 59(2): E107-E119.

21. Paterson P, Meurice F, Stanberry LR, Glismann S, Rosenthal SL, Larson HJ, Vaccine hesitancy and healthcare providers. Vaccine, 2016; 34(52): 67006706.

22. Prymula R, Siegrist CA, Chlibek R, Zemlickova H, Vackova M, Smetana J, Lommel P, Kaliskova E, Borys D, Schuerman L, Effect of prophylactic paracetamol administration at time of vaccination on febrile reactions and antibody responses in children: two open-label, randomised controlled trials. Lancet, 2009; 374(9698): 1339-1350.

23. Rose MA, Juergens C, Schomoele-Thoma B, Gruber WC, Baker S, An open-label randomized clinical trial of prophylactic paracetamol coadministered with 7-valent pneumococcal conjugate vaccine and hexavalent diphtheria toxoid, tetanus toxoid, 3-component acellular pertussis, hepatitis B, inactivated poliovirus, and Haemophilus influenzae type b. BMC Pediatr., 2013; 13: 98: 1-8.

24. Section on Clinical Pharmacology and Therapeutics, Committee on Drugs, Sullivan J, Farrar H, Fever and antipyretic use in children. Pediatrics, 2011; 127(3): 580-587.

25. Sigurdsson $\mathrm{S}$, Kristinsson $\mathrm{K}$, Erlendsdottir H, Hrafnkelsson B, Haraldsson A, Decreased incidence of respiratory infections in children after vaccination with ten-valent pneumococcal vaccine. Pediatr Infect Dis J., 2015; 34(12): 1385-1390.

26. van Panhuis WG, Grefenstette J, Jung SY, Chok NS, Cross A, Eng H, Lee BY, Zadorozhny V, Brown S, Cummings D, Burke DS, Contagious diseases in the United States from 1888 to the present. $N$ Engl J Med., 2013; 369(22): 2152-2158.

27. WHO vaccine-preventable diseases: monitoring system. 2018 global summary (available at apps.who.int).

28. WHO. Immunization coverage (available at www.who.int).

29. WHO. Safety of Medicines - A Guide to Detecting and Reporting Adverse Drug Reactions - Why Health Professionals Need to Take Action (available at http://apps.who.int).

30. Wysocki J, Center KJ, Brzostek J, Majda-Stanislawska E, Szymanski H, Szenborn L, Czajka H, Hasiec B, Dziduch J, Jackowska T, Witor A, Kopińska E, Konior R, Giardina PC, Sundaraiyer V, Patterson S, Gruber WC, Scott DA, Gurtman A, A randomized study of fever prophylaxis and the immunogenicity of routine pediatric vaccinations. Vaccine, 2017; 35(15): 1926-1935.

31. Zangwill KM, Eriksen E, Lee M, Lee J, Marcy S, Friedland LR, Weston W, Howe B, Ward JI, A population-based, postlicensure evaluation of the safety of a combination diphtheria, tetanus, acellular pertussis, hepatitis $\mathrm{B}$, and inactivated poliovirus vaccine in a large managed care organization. Pediatrics, 2008; 122(6): e1179-1185.

32. Zepp F, Schmitt HJ, Cleerbout J, Verstraeten T, Schuerman L, Jacquet JM, Review of 8 years of experience with Infanrix hexa ${ }^{\mathrm{TM}}$ (DTPa-HBV-IPV/ Hib hexavalent vaccine). Exp Rev Vaccines, 2009; 8(6): 663-678. 